http://jmscr.igmpublication.org/home/

ISSN (e)-2347-176x ISSN (p) 2455-0450

crossref DOI: https://dx.doi.org/10.18535/jmscr/v7i7.12

\title{
Squemous Cell Carcinoma- Uncontrolled Growth of Abnormal Cells
}

\section{Authors
Abhishek $^{1 *}$, Kunal Kumar $^{2}$, Ankit $^{3}{ }^{3}$, Pragjyoti Baruah $^{4}$, Vinod Kumar $^{5}$, Nirma Bharati ${ }^{6}$}

${ }^{1}$ Assistant Professor, Dentistry Department, Katihar Medical College \& Hospital, Al-Karim University, Katihar, Bihar

${ }^{2}$ Senior Resident, Department of Dentistry, Patna Medical College \& Hospital, Patna, Bihar

${ }^{3}$ Private Practitioner, Buxar, Bihar

${ }^{4}$ Private Practitioner, Dhemaji, Assam

${ }^{5}$ Assistant Professor, Dentistry Department, Katihar Medical College \& Hospital, Al-Karim University, Katihar, Bihar

${ }^{6}$ Tutor, Dentistry Department, Katihar Medical College \& Hospital,Al-Karim University, Katihar, Bihar. *Corresponding Author

\section{Dr Abhishek}

Assistant Professor, Dentistry Department, Katihar Medical College \& Hospital, Al-Karim University,

Katihar, Bihar

\section{Abstract}

Carcinoma is word of fear for the person who was diagnosed by a Doctor. Squamous cell Carcinoma is the most common and variant oral malignancy found in the oral cavity. Existence of this type malignancy is approx. ninety percent around the world.

Keyword: Carcinoma, Malignancy, Katihar Medical College, Al-Karim University.

\section{Introduction}

The Squamous cell carcinoma (SCC) oral Cancer is the $6^{\text {th }}$ most common cancer in the world and it mainly due to the tobacco chewing andpanmasala. ${ }^{1}$ The existence of oral squamous cell carcinoma is $90 \%$ around the word. ${ }^{2}$ It is the most common malignant lesion of the oral cavity and tenth most common cause of death. ${ }^{3}$ In male the chances of intra oral malignancy increases with increase in age., ${ }^{4,5}$

\section{Case Report}

A 51-year-old male was referred to dentistry department, Katihar medical college, Al-karim
University, Katihar, Bihar (India) for the evaluation of a painless right buccal mucosal mass with 3 to 4 months duration. The patient's past medical history indicated diabetes mellitus (fasting blood sugar $=280 \mathrm{mg} / \mathrm{dl}$ ). He also refuses to take any use of alcohol and cigarettes. The patient was a businessman and had no other close relationship to harmful chemical or industrial substances. In the clinical examination of the left posterior buccal mucosa, a mass of irregular surface, was identified (figure $1 \mathrm{a} \&$ figure $1 \mathrm{~b}$ ). The lesion had a soft-to-firm consistency. There was no evidence of the neck lymphadenopathy. An incisional biopsy was performed under local 
anaesthesia. Microscopic sections of the lesion showed sheets of malignant squamous epithelium invading into the lamina propria. The epithelial cells showed pleomorphism, hyperchromatism and remarkable mitotic features without keratin pearl formation. (figure 2).

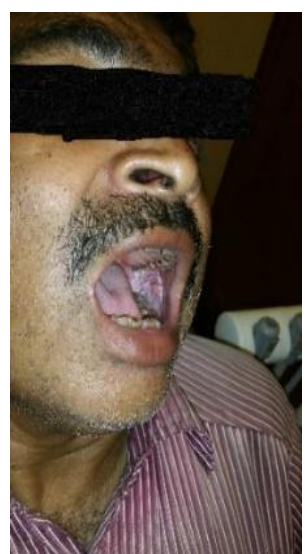

Figure: 1a

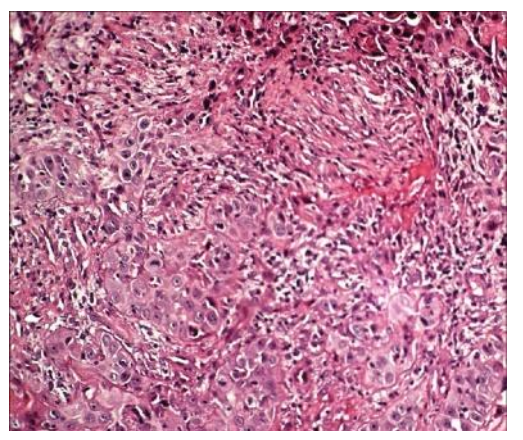

Figure 2

\section{Discussion}

The SCC is more in male rather in female. The prevalence of SCC is due to the poor oral hygiene of the oral cavity. Periodontitis is the main associated factor for the occurrence of $\mathrm{SCC} .^{6-8}$ Trauma, Dental filling less than idea, ill fitting denture, wide range of exposure (tobacco use, pan masala, cigarette), medical treatment such as radiation, hormone drug may contribute to etiological factor of SCC.

\section{Conclusion}

In this paper we found rare occurrence of squamous cell carcinoma in the lower left back region of jaw.

\section{Consent}

Patient was informed for the publication and written consent was taken from the patient.

\section{References}

1. Shah JP, Gil Z. Current concepts in management of oral cancer--surgery. Oral Oncol. 2009 Apr-May;45(4-5):394-401.

2. Bagan J, Sarrion G, Jimenez Y. Oral cancer: clinical features.Oral Oncol. 2010 Jun;46(6):414-7.

3. Falaki F, Delavarian Z, Pakfetrat A, Mohtasham N, Shirazian S. Oral Squamous cell carcinoma with an unusual clinical manifestation: a case report. Cases J. 2009 Apr 20;2:6608.

4. Seoane J, Warnakulasuriya S, VarelaCentelles P, Esparza G, Dios PD. Oral cancer: experiences and diagnostic abilities elicited by dentists in NorthWestern Spain. Oral Disease. 2006;12 (5):482-492.

5. Nevile BW, Damm DD, Allen CM, Bouqout JE. 2. Philadelphia: WB Saunders; 2002. Oral \& Maxillofacial Pathology; pp. 356-366.

6. Tezal M, Grossi SG, Genco RJ. Is periodontitis associated with oral neoplasms? J Periodontol 2005;76:406-10.

7. Guha N, Boffetta $P$, Wünsch Filho V, Eluf Neto J, Shangina O, Zaridze D, et al. Oral health and risk of squamous cell carcinoma of the head and neck and esophagus: Results of two multicentric case-control studies. Am J Epidemiol 2007;166:1159-73.

8. Tezal M, Sullivan MA, Hyland A, Marshall JR, Stoler D, Reid ME, et al. Chronic periodontitis and the incidence of head and neck squamous cell carcinoma. Cancer Epidemiol Biomarkers Prev 2009;18:2406-12. 